\title{
Specimens, slips and systems: Daniel Solander and the classification of nature at the world's first public museum, 1753-1768
}

\author{
Edwin D. Rose \\ University of Cambridge
}

\begin{abstract}
The British Museum, based in Montague House, Bloomsbury, opened its doors on 15 January 1759 , as the world's first state-owned public museum. The Museum's collection mostly originated from Sir Hans Sloane (1660-1753), whose vast holdings were purchased by Parliament shortly after his death. The largest component of this collection was objects of natural history, including a herbarium made up of 336 bound volumes, many of which were classified according to the late seventeenth century system of John Ray (1627-1705). The 1750s saw the emergence of Linnaean binomial nomenclature, following the publication of Carl Linnaeus' Species Plantarum (1753) and Systema Naturae (1758). In order to adopt this new system for their collections, the Trustees of the British Museum chose to employ the Swedish naturalist and former student of Linnaeus, Daniel Solander (1733-82) to reclassify the collection. Solander was ordered to devise a new system for classifying and cataloguing Sloane's natural history collection, which would allow both Linnaeans and those who followed earlier systems to access it. Solander's work was essential for allowing the British Museum to realise its aim of becoming a public centre of learning, adapting the collection to reflect the diversity of classificatory practices which were existent by the 1760s. This task engaged Solander until 1768, when he received an offer from Joseph Banks (1743-1820) to accompany him on HMS Endeavour to the Pacific.
\end{abstract}

On 11 January 1753, the celebrated naturalist, collector and physician Sir Hans Sloane (1660-1753) died at his home in Chelsea, four months before the publication of the first edition of Carl Linnaeus' Species Plantarum, which established the binomial naming system for all known plants. ${ }^{1}$ His extensive collections, including a vast herbarium of 336 volumes of dried plants, were purchased later that year by the British state for $£ 20,000$ and formed the foundation for the British Museum, the first state-owned public museum. ${ }^{2}$ This article analyses the treatment of Sloane's natural history specimens at the British Museum, with special reference to the herbarium, one of the few intact parts of his collection. Particular attention will be paid to the efforts of the Swedish systematist and former student of Carl Linnaeus (1707-78), Daniel Solander (1733-82), to rename and reclassify the Museum's 
natural history specimens according to the Linnaean system between 1763 and 1768, initiating the development of the first modern museum catalogues. This took place at the same time as the uneven emergence of Linnaean systematics in Britain from the early $1750 \mathrm{~s}$ through to the $1770 s^{3}$

Due to the natural history collection's vast size and the loss of much of the zoological material, this paper concentrates on Sloane's botanical collections. Many of Sloane's zoological specimens had decayed by the early nineteenth century. In 1823, the Liverpool physician Thomas Traill (1781-1862) noted that 'all Sloane's quadrupeds have been annihilated' and that the most commonly observed insects in the collection were 'moths, ptini and dermestes, busily employed amid the splendours of exotic plumage, or roaming through the fur of animals'. ${ }^{4}$ Sloane's rotting zoological specimens were deposited in the crypts of Montague House following more exotic acquisitions during the early nineteenth century, and were then subjected to 'a large fire being kindled in the courts of Montague House, into which the rotten or mutilated fragments of various zoological specimens were thrown'. A guard was moreover placed over this funeral pile, 'to prevent any sacrilegious hand from snatching a feather or a bone from destruction'. ${ }^{5}$ By contrast, Sloane's herbarium has remained largely intact along with its original catalogues. ${ }^{6}$

The natural history collection of the British Museum originated from Sloane's trip to Jamaica in 1687 , when he gathered over 800 new species of plants. These were organised according to the system of John Ray (1627-1705), who ordered plants according to their general physical resemblances. ${ }^{7}$ The main catalogues were Sloane's annotated copies of John Ray's Historia Plantarum (1686-1704) and his own publication, A Voyage to the Islands Madera, Barbados, Nieves, St Christophers and Jamaica (1707-25). ${ }^{8}$ When Sloane's collection was accessioned to the British Museum in 1753, an institution designed to preserve Sloane's legacy in the form of his collection and the systems of information management 
which surrounded it, it became increasingly apparent that the natural history specimens had to be revised in a way which reflected the Linnaean system of classification. In order to make the collection accessible to Linnaean naturalists, Solander relied on the existent cataloguing structures established by Sloane, over which he laid the Linnaean binomial naming system and forms of standardised description. However, the physical arrangement of the specimens was not altered to reflect the Linnaean system, preserving Sloane's original methods for locating specimens.

The examination of the changes made to the British Museum's natural history collections during the 1760 s presents a new understanding of the response to Linnaean systematics and binomial nomenclature in relation to the management of physical objects. In 1753, Linnaeus published Species Plantarum, in which he combined the binomial naming system with his sexual system of classification, which dated from the first edition of Systema Naturae (1735). ${ }^{9}$ Unusually, given the debates surrounding the use of the Linnaean system in Britain during the 1750s and 1760s, the Trustees of the British Museum accepted the Linnaean system of classification when it was combined with the binomial nomenclature first published in the 1753 edition of Species Plantarum. In applying these new methods of naming and ordering, however, a system for classifying and cataloguing had to be devised that would work not only for Linnaean naturalists but also for those who continued to use earlier methods of classification, responding to the British Museum's distinct public remit. ${ }^{10}$

As this article will suggest, Solander's work initiated a major change in the ways public collections were managed, essential for establishing the first modern museum cataloguing system and the British Museum as a centre for research into natural history. It has long been assumed Linnaean systematics gained a stable foothold in Britain as a result of James Edward Smith's purchase of the Linnaean collections in 1784, founding the Linnaean Society of London in $1788 .{ }^{11}$ However, the widespread use of Linnaean practices of 
managing information and classification had been established during the 1760s by Solander's work at the British Museum, an event which coincided with the publication of works such as William Hudson's Flora Anglica (1762) and Thomas Martyn's Plantae Cantabrigiensis (1763). ${ }^{12}$ Solander's activities firmly established the Linnaean system at one of the main institutional centres for British natural history which was vital for initiating advancements in the field during the late eighteenth and nineteenth centuries. ${ }^{13}$ Rather than emanating from a period of decline, as has been previously assumed, the interests of individuals such as Smith and Joseph Banks, a central figure in the promotion of research into natural history from the 1770 s to his death in 1820 , emerged from a time of great change in the practice of natural history, particularly following the incorporation of the binomial nomenclature into the Linnaean sexual system of classification during the 1750s. ${ }^{14}$ This resulted in efforts to revise existing collections during the 1750 s and 1760 s so they conformed to Linnaean practices, an activity propagated by Linnaean apostles such as Solander, throughout Europe. ${ }^{15}$

\section{From Ray to Linnaeus}

In order to understand the changes made to the British Museum's natural history collection during the 1760s, it is important to recognise the differences between the Linnaean system and that which had previously been employed to classify Sloane's collection. The introduction of binomial naming practices in Species Plantarum (1753) resulted in several changes to the previous approaches, in particular the practice of using polynomial names to describe species. This had been used by Sloane and John Ray (1626-1705), whose system of classification was the most widely used in Britain by the mid eighteenth century. ${ }^{16}$ Ray based the major categories in his system of classification on the general resemblances shared by different species of plants. For this, he was influenced by Andrea Cesalpino's De Plantis (1583), in which Cesalpino based his classification of plants on the similarities between the 
structural features of their fruits and seeds. ${ }^{17}$ However, Ray’s system used a greater variety of physical and external properties of plants than Cesalpino's; Ray initially divided plants into trees, shrubs or herbs and then ordered these according to a variety of physical characteristics, such as the number of cotyledons, shape of the leaves, the arrangement and shape of the flowers, as well as the characters of the fruits and seeds. ${ }^{18}$ In Historia Plantarum (16861704), one of the most significant attempts to produce an account which encompassed the entire world's flora, Ray classified plants into three broad categories; herbs, shrubs and trees. He then ordered these into different genera within which he listed the individual species. ${ }^{19}$ Ray ascribed to each species a polynomial name, which varied from one word to a paragraph in length, after which he described the physical features of the plant, often starting with its roots and moving up to the flowers and fruits. Similar to the names, these descriptions were not standardised and varied in length. ${ }^{20}$

Sloane used Ray's approach for classifying and describing plants in A Voyage to Jamaica (1707-25) and to order his personal herbarium collections, which make up the first seven volumes of the herbarium. ${ }^{21}$ The specimens in the rest of Sloane's herbarium are still in the state they were left by their original collectors, effectively an amalgamation of separate collections acquired by Sloane at various points throughout his life, later incorporated within a single unit. ${ }^{22}$ For instance, in 1718 Sloane acquired 106 volumes of the apothecary James Petiver's (c. 1665-1718) herbarium, each volume of which contains specimens from a different geographical locality. Each volume of specimens was then ordered according to Ray's system of classification. ${ }^{23}$ A unifying aspect of these collections was Sloane's annotated copy of Ray's Historia Plantarum which served as a partial index, therefore providing a tool for those familiar with Ray's system to use for the location of specific specimens within the bound volumes of the herbarium. ${ }^{24}$ For instance, the annotation ' $\mathrm{H}$. S. 127. p. 38', at the top of page 613 in Sloane's copy of Historia Plantarum, relates to the 
specimen which can be found at Hortus Siccus, volume 127 folio $38 .^{25}$ These annotations are mostly in the hand of Johann Amman (c. 1707-41), Sloane's curator from c. 1729-36, or, when they relate to Sloane's personal collections, in the hand of Sloane himself. ${ }^{26}$ Amman's page references to Historia Plantarum accompany many of the specimens in the herbarium, directly associating the physical objects and this printed work, although the specimens were not necessarily arranged according to the approach outlined by Ray. ${ }^{27}$

In comparison to Ray, Linnaeus narrowed the range of characteristics used to define the main groups of plants. Linnaeus devised the sexual system of plant classification which relied on the number and distribution of the pistils and stamens in the flowers of plants. He defined this as an artificial system, due to the use of only two characters to define the major groups, and resulting in a tendency to separate species with a high degree of overall similarity. ${ }^{28}$ These specific features formed the foundation for Linnaeus' division of plants, which he separated into twenty-four classes based on the number of stamens and their distribution within flowers. ${ }^{29}$ These classes were then sub-divided into orders, based on the number of pistils, which were then divided into genera, before being separated into individual species. In Species Plantarum (1753), Linnaeus used binomial names consistently for the first time, giving a generic and specific name for each plant. Unlike the polynomials used by Ray, which were designed to give a brief description of the plant, Linnaean binomials were designed to give the species a definitive name which would establish its place within the lower ranks of the hierarchic system of classification. Although the binomial name did not necessarily describe the plant, Linnaeus often chose a name that defined a particular physical feature, geographical region or habitat preference. Following the publication of Species Plantarum, the advantages of binomials were quickly recognised in Britain by naturalists such as William Withering, William Hudson, Thomas Martyn and John Hill. ${ }^{30}$ 
A typical example of a species of plant described by both Ray and Linnaeus can be found in the case of a species of broad leaved African grass, the vernacular name for which is Carrycillo, which Ray named Gramen Paniceum majus, spica simplici lavi, granis petolis infidentibus. This polynomial describes multiple physical features of the plant, which Ray took from Sloane's description in A Voyage to Jamaica.$^{31}$ In comparison, the name Linnaeus ascribed to this species was Olyra latifolia L., a binomial which specifies the genus and the species and indicates that this particular species has broad leaves; there was only one species classified under this particular genus in the 1762-63 edition of Species Plantarum. ${ }^{32}$ Ray and Linnaeus based their descriptions of this species on the specimen collected by Sloane in 1687; however, only Ray had the opportunity to study it in detail. ${ }^{33}$ Linnaeus, who only visited Sloane and examined his herbaria for a short time in August 1736, had to rely on the copper plate images and descriptions in A Voyage to Jamaica. ${ }^{34}$ In comparison to those in Historia Plantarum, Linnaeus' descriptions in Species Plantarum and Systema Naturae followed a standardised format, often eliminating verbs and concentrating on the floral parts of the plants, establishing the position Linnaeus gave each species within the sexual system of classification. ${ }^{35}$ These standardised methods of description and binomial naming system were central to Solander's reclassification of the British Museum's collection, allowing him to concentrate on individual specimens, emphasising the lower ranks of genus and species.

\section{Constructing the first public collection}

Following Sloane's death in 1753 to the opening of the British Museum to the public in 1759, several changes were made to the natural history collection after it was moved from the Manor of Chelsea to Montague House, Bloomsbury in 1756. To understand these changes and the state of the collection by the early 1760 s, it is important to consider its precise spatial arrangement. Throughout the 1750 s, the main figure responsible for the natural history 
specimens was James Empson (d. 1765), who had been employed by Sloane to curate his collection since $1741 .{ }^{36}$ Other individuals with a vested interest in the collection included Sloane's heirs, the Cadogans and Stanleys, the senior librarian of the British Museum, Dr. Gowin Knight, along with some of the most active Trustees. Among these were George Parker, the Earl of Macclesfield and President of the Royal Society; Peter Collinson (16941768), a merchant and botanical entrepreneur, and Dr. William Watson (1715-87), a notable physician. $^{37}$

Sloane's collections remained in Chelsea until the summer of 1756 when they were transported to Montague House (figure 1). ${ }^{38}$ Empson was the main overseer for its transportation and reconstruction in the British Museum, as implied by his proposal for the displaying of Sloane's curiosities, submitted to the Trustees on 29 August $1756{ }^{39}$ Throughout his report, Empson maintained that Sloane's collections should be placed 'in the same manner as they stand now at Chelsea', a method which would reconstruct the experience of visiting the collection and prevent parts of it from becoming disorganised during the process of transportation. Empson, who gave regular tours of the collection after Sloane's death, recognised that the reconstruction of Sloane's scholarly methods of display and ordering would ensure that the collection would maintain its integrity as a research tool and be appreciated by more general visitors. ${ }^{40}$

Transferring the Sloane collection from its premises in a sixteenth-century manor house to Montague House, which was originally constructed in the late seventeenth century, resulted in it being placed in a series of rooms on the second state storey (that being the second level of state rooms), unlike its previous arrangement in a single $110 \mathrm{ft}$. long gallery. ${ }^{41}$ However, Empson still planned to replicate Sloane's methods of arrangement, classifying the natural history specimens according to the system of John Ray, suggesting this was beneficial for scholarly and general visitors of the Museum. The herbarium volumes were ordered, from 
volume 1 to 336, and placed on book cases, alongside Sloane's folio natural history books, which included his working copies of Ray's Historia Plantarum and A Voyage to Jamaica, both of which were annotated by Sloane and his successive curators. ${ }^{42}$ In order to display Sloane's collections appropriately, the Trustees initially allowed a number of cabinet makers to 'see the cabinet already finished'. This was one of Sloane's cabinets, which the Trustees hoped to replicate. They could not use the original cabinets because of claims by Sloane's heirs, Lady Cadogan and Sarah Stanley, who added to their 'List of particulars which Lady Cadogan and Mrs. Stanley apprehend to be theirs', 'The cabinets, which we apprehend not to belong to the Collection after the particulars they contain are removed'. ${ }^{43}$ The Trustees asked the craftsmen to 'deliver proposals sealed up to the next committee', in which the cabinet makers specified the prices they were going to charge for fitting cabinets and book cases in Montague House, modelled on those Sloane had used at Chelsea. ${ }^{44}$

To fit new cases and cabinets in Montague House, the Trustees employed the cabinet maker John Phillips (1708/9-75) who quoted a price of £3-6-6 per running foot of shelving. ${ }^{45}$ They wished for these to be custom-made for parts of the collection, instructing Phillips to design and fit cabinets and cases to the designated rooms so as to accommodate specific aspects of the collection. Examples include the herbarium and other folio volumes, the cases for which were designed according to a set of dimensions specified by Empson (figure 2). ${ }^{46}$ The construction of cabinets specifically designed to accommodate certain parts of Sloane's collection suggests that particular care was taken to reconstruct its original arrangement in the British Museum, preserving Sloane's legacy.

The main problem Empson encountered after the transportation of Sloane's collections to Bloomsbury was that, although the different parts of the natural history collection did have a similar physical arrangement to that used by Sloane, these were split between separate museum departments, managed by different curators. This is most apparent 
from Empson's comments on the state of Sloane's herbarium. The first eight volumes, which contain the plants Sloane persenally had collected in the West Indies, were originally placed in the Department of Natural Curiosities with the other botanical specimens, such as dried fruits and seeds. The other 328 volumes, however, were placed among the natural history books in the Library, fundamentally altering the structure of Sloane's botanical collection. ${ }^{47}$ Empson suggested that 'dried plants more properly belong to a museum than a library, as the above eight volumes contain matter of the same nature with those in the Hortus Siccus, and have been judged to belong to the Department of Natural Curiosities' ${ }^{48}$ This split between the volumes of Sloane's herbarium caused a number of problems with the cataloguing system: for instance, it was more difficult to use Sloane's copy of Ray's Historia Plantarum alongside all of the herbarium volumes once they were split between the Library, on the first state storey of Montague House, and the Department of Natural and Artificial Curiosities, on the second. ${ }^{49}$

The division of Sloane's Hortus Siccus from the rest of the botanical collection severed the relationship between the plant specimens and the plant parts, such as their seeds and dried fruits. Empson stated that 'it will appear very odd, if we, in the sight of these plants, should refer them [visitors] to the library'. ${ }^{50}$ The volumes of Sloane's herbarium were placed in the library because of the Trustees' concerns that the Department of Natural Curiosities would take on the appearance of a library, rather than a museum of natural history. Empson proposed that Sloane's herbarium should be stored in an oblong bureau in the middle of the room, a piece of furniture specially designed to accommodate the volumes, ensuring that there was minimal resemblance to a library. This method of displaying Sloane's herbarium would ensure that it was arranged according to a similar method to that used in Chelsea, and that the catalogues continued to function as a means for locating specific specimens. 
Empson was so concerned about the division of the herbarium that he suggested if his proposal was not approved, 'the above mentioned eight volumes of dried plants must be delivered to the library'. ${ }^{51}$ Despite Empson's proposal, the volumes of plants remained in the library department with Sloane's books. The first volumes of the herbarium seem to have joined the rest of the collection; Edmund Powlett's 1761 guide book mentioned they were in 'another part of Sir Hans Sloane's Library', kept among the natural history books. ${ }^{52}$ However, the herbarium appears to have been administered by the librarians from the Department of Natural and Artificial Curiosities, as demonstrated by the use of the collection by Empson, Solander and later curators. Although the natural history collections were kept on different floors at the British Museum, the proximity of the bound volumes containing the herbarium to the printed books reflects Sloane's arrangement of these items in his home at Chelsea. ${ }^{53}$ This shows that despite efforts to reconstruct Sloane's collections, the Trustees desired to create a modern 'department' of natural history that looked physically different from a library, resulting in the separation of two aspects of the botanical collection which had shared fundamental connections.

\section{Opening the collection for 'all students in Natural History' ${ }^{, 54}$}

Following the transfer of Sloane's collection, Empson was appointed to the role of Under Librarian for the Department of Natural and Artificial Curiosities. By the time the British Museum opened its doors in 1759 , the main concern of the Trustees was to increase access for the public and scholarly researchers by adapting the collections so as to conform to Linnaean classificatory principles. This work was encouraged by Trustees such as Watson and Collinson, advocates of Linnaean systematics, and the main lobbyists for Solander's employment as an assistant in $1763 .^{55}$ 
The British Museum Act, passed shortly after Sloane's death in 1753, stated that the 'collection may be preserved or maintained, not only for the inspection of and the entertainment of the learned and the curious, but for the general use and benefit of the public'. ${ }^{56}$ However, it must be acknowledged that the term 'public' in this period had a very different meaning to that in an era of modern museum access. Although admission was free, those wishing to visit the British Museum had to place a request in writing for tickets, following which they were allotted a specific time to view the collection. ${ }^{57}$ This process excluded most of the population. Applicants were admitted to the museum in groups of five to ten and kept under close supervision by the porters and curators. For the natural history collection, they were given a tour by Empson, who performed this role until his death in $1765 .^{58}$ Those who frequented the small, damp museum reading room, in the basement of Montague House, can be considered as members of the 'Literati'; the general qualification required for one to obtain a reader's pass was to be known to other readers. Prospective users of the collection had to come with letters of recommendation, ensuring that the holder was an active member of the Republic of Letters. ${ }^{59}$ The only people allowed to use the library without letters of recommendation were members of the learned societies, such as the Royal Society, the Society of Antiquaries, Trustees of the British Museum and Gresham Professors. This ensured, as stated by the first Principal Librarian and renowned inventor of highly magnetised steel, Dr. Gowin Knight (1713-72), that all 'improper persons can be excluded' ${ }^{60}$ Knight was appointed to the post of Principal Librarian of the British Museum in 1756 and initiated a reclassification of the Museum's natural history collections. ${ }^{61}$ This is demonstrated by a report he submitted to the Trustees in 1757 entitled 'A Plan for the general Distribution of Sir Hans Sloane's Collection', in which he stated that 'The greatest and most valuable part of the collection consists of things relating to natural history'. ${ }^{62}$ Knight made it clear that the confined space in the Department of Natural and Artificial Curiosities would 
make Sloane's herbarium volumes far more difficult for naturalists to access. He suggested that the herbarium should form the foundation of 'a collection quite new' and that they should store the plant specimens 'according to Linnaeus's system \& deposit them in a cabinet to be constructed for that purpose according to the proportions laid down by Linnaeus himself in Philosophia Botanica'. ${ }^{63}$ This was one of the most fundamental works of mid-eighteenthcentury botany, in which Linnaeus gave careful instructions on the best ways to maintain a herbarium, on individual sheets in tall thin cabinets. ${ }^{64}$ The doors of the Linnaean herbarium cabinets opened onto two narrow columns, divided into twenty-four separate compartments by shelves which could be easily moved to accommodate new material or rearrange specimens. Each compartment represented one of the twenty-four classes in Linnaeus' sexual system of classification. ${ }^{65}$ Linnaeus proposed that this method of organising plants was an efficient technique for establishing 'a herbarium according to the sexual system' ${ }^{66}$ However, the Linnaean practice of organising botanical specimens on separate sheets, allowing freedom to re-arrange the collection and accommodate new discoveries, was not compatible with the volumes of Sloane's herbarium. ${ }^{67}$ The bound volumes presented Knight with the choice of cutting up the volumes and redistributing the sheets, thus making the collection accessible to Linnaeans, or leaving the volumes in their original state so they could continue to be used by those who followed earlier methods. The radical move of cutting up the volumes would have gone against the Museum's mission of preserving Sloane's legacy. In the end, the decision was taken to leave the herbarium volumes in their original state, therefore resulting in the need for a new catalogue which followed Linnaean conventions. This is in sharp contrast to the fortune of the bound herbarium volumes held by the University of Oxford and many other institutions. During the late nineteenth century, efforts to incorporate earlier collections into the main herbarium resulted in the bound volumes being cut up. The specimens were then distributed on separate sheets throughout the rest of the collection. ${ }^{68}$ 
Knight, who possessed very little expertise in natural history, was following the requests of Collinson and Watson, who wrote in 1754 that Linnaeus' Species Plantarum is 'the master-piece of the most complete naturalist the world has seen' ${ }^{69}$ However, the Linnaean method still had its critics. These included the Welsh naturalist, Thomas Pennant (1726-98), who wrote in 1767 that Linnaeus' ornithological work was 'too superficial to be thought of, in madrepodology still more deficient. In fossils other judges than myself think him incompetent ${ }^{70}$ The popular author, Oliver Goldsmith (c. 1728-74), remarked that naturalists such as 'Linnaeus, have had only one aim, that of pointing out the object in nature, [and] discovering its name' and Ralph Brookes (d. 1793) wrote that Linnaeus' 'attempts to reduce the names of plants into a system, has rendered the study more difficult and more subject to error, than it would have been if the student had only used his sight for the distinguishing of plants'. ${ }^{71}$ These views reflect the main arguments of the Linnaean critics, the most prominent being Georges-Louis-Leclerc Comte de Buffon (1707-88), who believed Linnaeus' methods of standardised description did not adequately describe different species or follow the natural order. ${ }^{72}$ The initial undertaking to reclassify the British Museum's collection can be viewed as an attempt by Linnaeans, such as Collinson, Watson and Solander, to challenge these criticisms and prove that the Linnaean system was the most efficient for organising a natural history collection. However, Knight's lack of expertise in natural history and Empson's lack of knowledge of Linnaean systematics ensured that Sloane's herbarium remained relatively inaccessible to Linnaean naturalists until the 1760 s. The problems Linnaean naturalists experienced when accessing Sloane's botanical collection, and the inability of Knight or Empson to reclassify the herbarium, became even more pressing when the Museum opened its doors to visitors in 1759 . The inaccessibility of the Sloane collection led figures such as Collinson to urge Linnaeus' former student, Daniel Solander, to remain in England to work on the collection, rather than take up a professorship 
at the University of St Petersburg. ${ }^{73}$ Solander had been in England since 1760, originally sent by Linnaeus to John Ellis, head gardener at the Chelsea Physic Garden, to promote the Linnaean system. Solander soon became an important figure in British natural historical circles; in 1762, he assisted Watson with the ordering of the Montague House collection. ${ }^{74}$ Collinson was so desperate to keep Solander in Britain that he wrote to Linnaeus, who had lobbied on Solander's behalf for a professorship at the University of St Petersburg, commenting that if he was sent to Russia, Solander would be 'confined for years, no longer a free Agent, But Buried \& Lost in Obscurity'. ${ }^{75}$ Shortly before this, Collinson had written to Watson, suggesting that 'The gentleman [Empson] whose Department belongs to Natural History, is well qualified to give a descriptive catalogue of them', although Collinson maintained that Empson did not possess sufficient knowledge of the Linnaean system to reclassify the collection. ${ }^{76}$ Collinson believed Empson's inability to produce a systematic catalogue ensured that 'the Philosophick World is deprived of an Inconceivable fund of Knowledge', ${ }^{77}$ suggesting that Solander should be employed because of his 'Great Abilities' in such matters. According to a short memo, Empson was asked to review Collinson's letters to Watson before the next meeting. ${ }^{78}$

In his reply, Empson explained that although he had 'for some time past been referring several parts of the collection to Dr. Linnaeus' system', the time he was spending recording the information Sloane had relayed about the specimens, and escorting visitors through the collection, was infringing upon this work. He required additional assistance. ${ }^{79}$ Shortly after, Solander wrote a formal letter of application to Watson, in which he proposed that 'with the assistance of Mr. Empson, who well knows the History of these natural curiosities, the most essential part of them might be described \& properly ranked in a catalogue' ${ }^{80}$ Solander was formally hired on 4 March 1763 to create a Linnaean catalogue 
and reclassify the Museum's collections, a task which engaged him until 1768, when he received an offer to accompany Joseph Banks on the Endeavour.

\section{Solander's reclassification}

When Solander arrived at the Museum in 1763, he was greeted by possibly the largest natural history collection in Europe, much of it arranged according to a variety of early eighteenth century systems of classification, most prominently those devised by John Ray, Francis Willughby and Joseph Pitton De Tournefort. Many of the individual categories of natural history, such as plants, shells, fossils and insects, were already subject to a rigorous information management system, incorporating printed books, manuscripts and the labels on the specimens themselves. ${ }^{81}$ Sloane often used annotated printed books, in which many of his specimens were described and depicted, to catalogue and classify the collection. The already rigorous structures of organisation used by Sloane formed a basis for those used by Solander for its reclassification; this was the first time that Sloane's wide-ranging natural history collections were brought under a single unified information management system (figure 3). However, Solander had to ensure that a range of naturalists could continue to access the collection, as was apparent in his report to the Trustees dated 29 June 1765: 'Dr. Solander has taken care to describe all those [plants] so minutely, that any Botanist whatsoever, may range them according to his own favourite system'. ${ }^{82}$

Solander continued to use different copies of the same publications when he produced his catalogue to reclassify the references to the collection under the Linnaean system, relating the descriptions and images in these published works to the relevant specimens. Solander tended to use printed books lent to him by Banks, whom he first met when the latter applied for his first reader's ticket to the Museum in $1764 .^{83}$ Banks was part of a small group of Linnaean exponents, who were primarily based in London. Many of them gathered around 
Solander from the early 1760s, relying as they did upon Linnaeus' former pupil's expertise in natural history. ${ }^{84}$ In order to produce a catalogue for the first seven volumes of the British Museum's herbarium, Solander needed a clean copy of Sloane's publication A Voyage to Jamaica. This was a scarce and expensive book by the 1760s; even by 1733 the cost of five pounds made it inaccessible to many naturalists. In 1778, Banks received a letter from Richard Poore who commented that he was unable to obtain a copy of Sloane's work when in London, hindering his fieldwork in the West Indies. ${ }^{85}$ Solander, who only earned $£ 100$ annually, would have found a fresh copy of this book to be hugely expensive. Therefore, he used the copy of $A$ Voyage to Jamaica owned by Joseph Banks, who had the means to purchase such a book during the early $1760 \mathrm{~s}^{86}$

Solander's first task was to transcribe the annotated location codes from Sloane's personal copy of this work, which entered the Museum with the rest of the collection in $1756 .^{87}$ Additionally, Solander related each printed description and copper plate image to the physical specimen which was mounted opposite the original drawing in the herbarium. ${ }^{88}$ In addition to adding the specimen location numbers to Banks's copy of $A$ Voyage to Jamaica, he inserted the new Linnaean binomial names from the 1762-63 edition of Species Plantarum, a far more comprehensive edition when compared to that published in 1753, and consistently cited page references to this edition (figure 4). Solander's use of the reference numbers from Sloane's annotated copy of A Voyage to Jamaica shows that Sloane's original cataloguing system was the most efficient method available for locating specific specimens in the bound herbarium volumes. A typical example is the reference number 'H. S. 2: 7', which Solander transcribed from Sloane's copy of A Voyage to Jamaica into Banks's copy. This number acts as a location code for the specimen of Olyra latifolia L. at Hortus Siccus, volume 2 , folio 7 (figure 5). ${ }^{89}$ Solander's continued use of Sloane's cataloguing system was a result of the problems posed by the bound volumes, previously encountered by Knight. These 
ensured that Solander could not organise the physical specimens according to the Linnaean method without destroying the integrity of Sloane's work (something the Trustees and Empson thought it imperative to preserve) and making the collection inaccessible to naturalists who followed Ray's classificatory principles.

Solander's addition of the Linnaean binomial name for every species described in $A$ Voyage to Jamaica shows his Linnaean preference for systematic binomials over the descriptive polynomial names favoured by Sloane. ${ }^{90}$ The binomial name Solander ascribed to the type of Carrycillo was Olyra latifolia L., which came from the 1762-63 edition of Species Plantarum, underneath which he added the page reference to Linnaeus' work. ${ }^{91}$ In a similar manner to many Linnaeans, Solander believed that polynomials were cumbersome and inaccurate, a point he emphasised in the Philosophical Transactions, suggesting that none of the pre-Linnaean naturalists 'gave us a true Botanical name or description, much less referred it to its proper class, order or genus'. He maintained that this was apparent throughout 'the Botanical collections of Sir Hans Sloane, now in the British Museum' ${ }^{92}$ Despite his disapproval of polynomials, Solander did not erase or write over Sloane's names or descriptions in A Voyage to Jamaica, continuing to value them for their historical importance. ${ }^{93}$ Sloane's descriptions contained field observations and the polynomials were used by Linnaeus to formulate his descriptions in Species Plantarum, showing how Solander valued the relationship between these specimens and printed works in an historical manner, as essential resources for obtaining additional information on the species represented by the specimens in the collection. ${ }^{94}$ This is in contrast to earlier annotators of printed works, such as John Evelyn, who frequently erased information which he did not deem to be relevant. Isaac Newton, too, often erased older information, concentrating on the most up to date calculations. $^{95}$ 
Solander's use of printed works, such as A Voyage to Jamaica, which contained descriptions and images based on specimens in the collection, is again apparent in the herbarium volumes containing Japanese plants collected by the German physician and naturalist Engelbert Kaempfer (1651-1716), stored in volumes 211 and 213. ${ }^{96}$ Solander annotated Banks's copy of Kaempfer's Amoenitatum exoticarum (1712) in the same manner as A Voyage to Jamaica, providing reference numbers which relate the plants described in the printed text to the specific specimens in the herbarium, besides adding page references to Species Plantarum and the relevant binomial names. ${ }^{97}$ However, Solander seems to have encountered problems with these particular specimens; in a report to the Trustees dated 29 June 1765 he mentioned that 'in general the [herbarium] specimens have been very good and compleat, except in Dr. Kaempfer's Hortus Siccus, which seems to be made up of spare specimens' ${ }^{98}$ This is apparent through the examination of these specimens, many of which do not bear flower and fruit, comprising instead only a few leaves. A typical example is the specimen to which Solander ascribed the Linnaean binomial name Fagara piperita (Zanthoxylum piperitum (L.) DC). He noted this name in the margin next to the relevant description in Banks's copy of Kaempfer's work and added a reference number to the fragmentary herbarium specimen. He placed a new label next to the specimen in the herbarium, on which he wrote the Linnaean binomial for this species. ${ }^{99}$

Solander's attempts to apply Linnaean conventions to the cataloguing systems are similar to the efforts of contemporary curators at the Ashmolean Museum, who added Linnaean conventions to the natural history collections. ${ }^{100}$ This was a result of William Huddesford's desires to reform the museum as a modern institution during the $1760 \mathrm{~s}$, although little evidence for this activity seems to survive in the botanical collections from this period. ${ }^{101}$ Solander's reclassification, whilst keeping Sloane's original arrangement of the specimens, was necessary for adjusting the British Museum's herbarium so it could become a 
resource which reflected different classificatory practices in use during the 1760s. This effectively unified the entire collection under a single Linnaean management system, although the physical order of the specimens was not altered.

\section{Access and Organisation}

On 22 February 1765, Solander reported to the Trustees that 'Mr Empson is taken very ill' and had ceased work on the collections. ${ }^{102}$ After Empson's death in June, Solander was appointed to assist Matthew Maty, the new Under Librarian for Natural and Artificial Productions. ${ }^{103}$ From this point, Solander appears to have made far more progress with his catalogue, a result of him no longer being 'interrupted $\&$ hindered by the Companies passing three times a day through the rooms where he has been at work'. ${ }^{104}$ In his original letter of application to work at the British Museum, Solander described the Linnaean catalogue he hoped to make for Sloane's natural history collection:

A catalogue such as I should think proper and fit for this purpose, should consist of: the generical Name with a differentia specifica and a trivial name; a good Synonyme - the native country - the use, if any - and in case it was a new subject, then to add a short description. ${ }^{105}$

This took the form of a 'Manuscript Slip Catalogue', essentially a series of unbound index cards of a uniform size of 4 " $\times 6 "(10.16 \mathrm{~cm} \times 15.24 \mathrm{~cm})$, stored inside a set of twentyfour Solander boxes, each of which contained slips relating to one of the twenty-four Linnaean classes based on the number of stamens in the flowers of plants. ${ }^{106}$ This catalogue appears to have been produced at the same time as the annotations in the related printed books which served as indices. Many of these books, along with the 'Manuscript Slip Catalogue', accompanied Banks and Solander on the Endeavour in 1768, thus showing that these annotations and slips were produced simultaneously as Solander went through the herbarium during the mid-1760s. These manuscript slips could be re-arranged to accommodate new species within the systematic order, in a similar manner to that proposed 
by Linnaeus for the arrangement of a herbarium collection. ${ }^{107}$ Solander probably recognised the advantages of working with slips of paper when he catalogued the Swedish Royal natural history collections alongside his tutor and mentor Linnaeus, although the slips produced from this work were of a different format and designed as a manuscript for a publication. ${ }^{108}$ The slips Solander used at the British Museum were designed to represent and describe a species; they could then be kept in a working order alongside the physical collection. The slips applied a Linnaean classification to the Museum's collection and could be continually added to as new species were acquired. This feature became particularly valuable when he took them on Cook's first voyage to the South Seas (1768-71), over the course of which Solander added slips concerning over 1400 new plant species. Solander started using these slips to catalogue Sloane's fossils, insects and plants during the winter of 1763-4, at least five years before Linnaeus realised the practicality of this sort of paper technology. ${ }^{109}$

By the closing months of 1765 , Solander was making steady progress on his task of reclassifying Sloane's herbarium collection. He reported that 'From the number of Volumes that are examined, Dr. Solander thinks that he has at least described between three and four Thousand plants'. ${ }^{110}$ Solander added that he was going to begin cataloguing the volumes of European and American plants although 'they are before pretty well known [and] will not take up so long time'. ${ }^{111}$ The majority of American and European plants, which included Sloane's Jamaican collections, were catalogued between 1765 and 1768, by Solander, who enlisted the additional assistance of Hermann Spöring, a Finnish instrument maker and surgeon, shortly after Easter $1766 .{ }^{112}$ Solander hired Spöring because he had 'some skill in natural history', a great advantage when compared to his previous unnamed assistant who could only 'copy out his manuscript notes' and was 'not of use to Dr. Solander in anything else'. 113 
Solander elevated the 'Manuscript Slip Catalogue' over Sloane's existing cataloguing system, which, in the case of the botanical collection, took the form of his annotated copies of A Voyage to Jamaica and Historia Plantarum. Empson had previously suggested these should 'serve as an index to all the Volumes of Sir Hans Sloane's Hortus Siccus'. ${ }^{114}$ Although some of Solander's manuscript slips did provide location codes for specific specimens in the Sloane herbarium, these were not always noted; their main task was to provide a Linnaean classification for all of the species in the collection, allowing Linnaean naturalists to trace the references to Sloane's catalogues, such as A Voyage to Jamaica, to locate specific specimens. These slips were designed in accordance to the description of a catalogue Solander proposed in his letter to the Trustees in 1763; each contains information on an individual species and has the genus name and page reference to Species Plantarum at the top, followed by notes on that species and a reference to the specific catalogue in the Museum collection. ${ }^{115}$ Solander's ideas of what constituted a catalogue were very different from what the Trustees envisaged; they anticipated a smartly bound inventory of the collection as opposed to detailed systematically arranged descriptions on manuscript slips. ${ }^{116}$ In order to satisfy the Trustees, Solander eventually gave Spöring the task of creating an inventory catalogue, of which only one volume survives, entitled 'Descriptions of plants from various parts of the world'. ${ }^{117}$ This shows that there were very different notions of how a catalogue should be constructed; the Trustees evidently expected a catalogue to resemble the bound volumes used by Sloane, similar to those used in the seventeenth century. ${ }^{118}$ However, this concept was overrun by the flexible nature of the slip catalogue for managing and rearranging information, features which were consistently recognised in museum collections, ensuring the success of these paper technologies. ${ }^{119}$

Slips which refer to specimens from Sloane's Jamaican collections are distributed throughout the 'Manuscript Slip Catalogue'. A typical example can be found in the slip 
which refers to the figure in A Voyage to Jamaica depicting the species Arum sagittcefolium (Xanthosoma sagittifolium (L.) Schott) or the Arrowleaf Elephant's Ear, on which Solander cited A Voyage to Jamaica first, and then referred to Leonard Plukenet's earlier work, Phytographia (1691-92) (figure 6). ${ }^{120}$ Solander's reference to the table which contains an image of the specimen in A Voyage to Jamaica, rather than to the printed text on the morphology and habitat of the plant, reflects Linnaeus' consistent use of the images in Sloane's work for Species Plantarum. ${ }^{121}$ Solander cited Species Plantarum at the beginning of his description of every known plant mentioned in the catalogue, showing how he was placing each specimen in its historical context, tracing it from Linnaeus, through Sloane, and then associating it with earlier descriptions. Next to each image in Banks's copy of Sloane's work, Solander has annotated the Linnaean binomial name for the species mentioned in the 'Manuscript Slip Catalogue', citing the page reference in Species Plantarum and giving the page reference for the relevant textual description in the main body of $A$ Voyage to Jamaica (figure 7). ${ }^{122}$ This allows those using the 'Manuscript Slip Catalogue' to trace the reference back to the image in A Voyage to Jamaica, on which Linnaeus based his descriptions for Species Plantarum. Moreover, the user can follow the annotated page number to the related description in Sloane's work, next to which Solander has annotated the binomial and reference code which can in turn be traced to the physical specimen and original drawing in the herbarium. ${ }^{123}$ Solander's annotated references emphasise that the descriptions and images in the Voyage to Jamaica consistently refer back to the herbarium specimens in different, although complementary, ways. ${ }^{124}$ These images effectively served as a portable collection; they were far easier to consult than the large herbarium volumes, providing a facsimile of the collection which could be easily transported. There was a natural incentive for Banks and Solander to take this copy of $A$ Voyage to Jamaica on the Endeavour voyage in $1768 .{ }^{125}$ 
The manuscript slips show that Solander based the binomial names and the general order of slips for the herbarium on that outlined by Linnaeus in the most recent edition of Species Plantarum (1762-63). Solander's citation of this work legitimised the binomial he ascribed to each specimen described in A Voyage to Jamaica and all of those he added in the form of labels to the Museum's botanical collections. This can be seen in the case of Arum sagittcefolium, a species Sloane collected in Madeira and the Caribbean, the binomial name for which Solander annotated in Banks's copy of A Voyage to Jamaica. ${ }^{126}$ If the page reference in the annotation is followed to Solander's working copy of Species Plantarum, the abbreviation 'Mscr*' (manuscript) can be found next to the entry for this species of Arum on pages $1369-1370 .{ }^{127}$ This indicates that Solander recorded this specimen in his 'Manuscript Slip Catalogue', showing that there is a physical example of the species in the museum collection. These references to the 'Manuscript Slip Catalogue' appear consistently, annotated next to species from the British Museum herbarium and examples of the same previously discovered species acquired by Banks and Solander on Cook's first voyage, descriptions of which were formulated by Linnaeus and published in Species Plantarum. ${ }^{128}$ After indicating that the specimen on which Linnaeus based his description of a particular species is in the Museum, it is then possible for those who follow Solander's catalogue to trace the references given by Linnaeus in the printed text and by Solander in the 'Manuscript Slip Catalogue' to Sloane's description and image, which represents the physical specimen. ${ }^{129}$ This emphasised that some of the specimens used for the descriptions in Species Plantarum were held by the Museum, essentially forming a fixed and important point of reference for Linnaean naturalists. Thus the British Museum's collection was established as one of the main European and Linnaean centres for natural historical reference, a task continued by British Museum curators until well into the nineteenth century. ${ }^{130}$ 
The paper slip, which was kept in close proximity to Solander's copy of Species Plantarum, was relatively easy to locate by those who were familiar with the Linnaean method of ordering of different species according to the sexual system of classification. By the late 1760s, these slips were in an arrangement based on that outlined in the 1762-63 edition of Species Plantarum; each of the twenty-four Solander boxes, in which they were formerly stored, contained slips all relating one of the twenty-four Linnaean classes, arranged according to orders, genera and individual species. The slip relating to the species Arum sagittcefolium was kept in the box designated for species from the Linnaean class Gynandria, the twentieth of the twenty-four classes. The loose nature of the slips allowed for their rearrangement following the publication of new editions of Species Plantarum or the discovery and addition of new species to the museum collection, and later Joseph Banks's collection, into which these slips were incorporated following their return from the Endeavour voyage in 1771.

The copy of Species Plantarum which Banks and Solander took on the Endeavour voyage is extensively annotated and interleaved, although, rather than being in Solander's hand, the majority of marginalia appear to be by Spöring. ${ }^{131}$ Solander took this copy on board the Endeavour in 1768 and the annotations on the interleaved pages reflect his continual acquisition of new species as the voyage progressed, representing the Linnaean system's ability directly to absorb large numbers of new species. ${ }^{132}$ Spöring died in 1771 , so he must have added these annotations for the Museum specimens when he had access to the collection, from the spring of 1766 to the summer of $1768 .{ }^{133}$ Solander's use of the most recent edition of Species Plantarum was essential for gaining the support of Linnaean scholars, ensuring that it was possible for them to use Sloane's herbarium. This addition of new references to the most recent edition of Species Plantarum for the specimens in Sloane's herbarium satisfied Linnaean Trustees such as Watson and Collinson, and transformed the 
British Museum into one of the first intellectual strongholds of Linnaean systematics in eighteenth-century Britain. $^{134}$

\section{Solander's new Linnaean Labels}

The Linnaean binomial determinations attached by Solander to the majority of specimens in Sloane's natural history collection between 1764 and 1768 were of central importance to his new information management system. On 21 February 1768, Solander recorded in his department note book that 'Proper names have been wrote on Labels to the plants'. ${ }^{135}$ These new labels, which Solander attached to specimens in the first and second volumes of Sloane's Jamaican collections, provide a direct link with his annotations in Banks's copy of A Voyage to Jamaica and Species Plantarum. These labels perform the task of giving an alternative binomial name for Linnaean naturalists whilst keeping the polynomial names favoured by those who continued to use Ray's system. ${ }^{136}$ A typical example can be found next to the specimen he labelled Marcgravia umbellata L., using the name from the 1762-63 edition of Species Plantarum, a species of flowering vine native to the Lesser Antilles. ${ }^{137}$ In most cases, Solander placed his label in close proximity to Sloane's original label, which gives the polynomial and page references to Sloane's earlier work Catalogus Plantarum quae in Insula Jamaica sponte proveniunt (1696), as well as A Voyage to Jamaica and Ray's Historia Plantarum (Figure 9). ${ }^{138}$ Solander's labels, which regularly cited 'Linn' for Linnaeus, gave the Sloane herbarium a new legitimacy, as a professionally classified collection which adhered to certain Linnaean conventions. ${ }^{139}$

The fact that Solander did not remove or place his binomial determination over Sloane's original label shows that he continued to value these references in an historical sense, making it possible for the user to trace them to Solander's annotations in A Voyage to Jamaica, in which, on the corresponding page, Solander's annotated binomial name for this 
particular specimen can be found. ${ }^{140}$ The adjacent citation of Species Plantarum allowed naturalists to place this particular species within the Linnaean systematic order. However, Solander only applied these determinations to the first two volumes of Sloane's Jamaican plants, possibly a result of his having access to Banks's copy of A Voyage to Jamaica by the late 1760s, which gave him the opportunity to add new Linnaean binomials to the descriptions of every plant in the collection. Linnaean scholars who used the collection could now easily refer to the annotations in Banks's copy of a Voyage to Jamaica, Species Plantarum, and those on the specimen itself.

Banks appears to have allowed Solander to use his copy of $A$ Voyage to Jamaica for the Museum collection between 1765 and 1768, possibly lending it to Solander when the latter journeyed to Newfoundland and Labrador in 1766. Once Solander had access to a clean copy of Sloane's work, it was no longer essential to add binomial determinations to the rest of Sloane's Jamaican hortus siccus — by tracing Sloane's original reference back to Banks's copy of A Voyage to Jamaica, the user could easily find the binomial and reference to Linnaeus' Species Plantarum inscribed next to every entry and copper plate image. ${ }^{141}$ The use of this annotated printed work alongside the specimens and manuscript slips shows how Solander laid the foundations for modern museum cataloguing systems, initiating a shift away from the use of bound volumes to more flexible paper technologies. Although Solander ascribed each specimen a binomial name, he laid the Linnaean system of classification over Sloane's older cataloguing system, ensuring this still functioned as a resource for the location of specific specimens.

\section{Reclassifying the Entomological Collections}

Solander applied his labelling technique throughout Sloane's natural history collection. In September 1764 Solander reported to the Trustees that he had 'made a Systematic Catalogue 
of the greatest part of the animals', including 'The insects that are deposited on the tables in the two rooms called the insect room and the spirit room and them that were preserved in some books [sic]'. ${ }^{142}$ Sloane appears to have ordered his insect collections in a similar manner to that outlined by Ray in his posthumous Historia Insectorum (1710), a work Sloane had a direct hand in seeing through the press. ${ }^{143}$ Comparable to the approach used for plants in Historia Plantarum, Ray's classification of insects relied on a range of physical features, habitat and behaviour, although it did not standardise descriptions or polynomial names. ${ }^{144}$

Similar to Ray, Linnaeus relied on a range of physical features for his classification of insects in Systema Naturae, initially basing the orders within the class Insecta on the presence and physical shape of the wings. ${ }^{145}$ However, unlike Ray, Linnaeus consistently used binomial names and developed a standardised practice of description, similar to that he used in Species Plantarum. ${ }^{146}$ These naming and descriptive practices were the main aspects of the Linnaean system which Solander applied to the British Museum's zoological collection, ascribing each specimen a label, on which he inscribed the Linnaean binomial, citing the name given in the 1758 edition of Systema Naturae (the first edition to consistently use binomial names). Additionally, Solander gave each species a manuscript slip which he laid out in much the same way as those made out for plants, the Linnaean binomial at the top and a list of publications in which it was described underneath. These zoological slips were then placed within Solander boxes, each of which contained a different Linnaean order.

The insects in the collection, many of which were unpinned and contained within small, glass-topped boxes, sealed with marbled paper, mostly originated in the collection of the apothecary James Petiver, which Sloane purchased for $£ 4000$ in $1718 .{ }^{147}$ According to Empson, these specimens were kept in the same room as Sloane's fossils, in the corner of the upper state storey of Montague House, laid out on the tables in the middle of the room. ${ }^{148}$ When he reclassified the entomological collections, Solander added new labels that related to 
the 'Manuscript Slip Catalogue', the binomial names on which he took from the 1758 edition of Systema Naturae. ${ }^{149}$ However, in a similar manner to his treatment of the plants, Solander was careful to preserve Sloane's and Petiver's original labels, effectively adding an additional layer to Sloane's original structure (Figure 10).

Throughout Sloane's insect collection, Solander ascribed each species a manuscript slip which he then referred back to the copper plate image depicting the specimen in the relevant publication. A typical example is a species of European water beetle which Solander ascribed the name Dytiscus semsitriatus (Dytiscus dimidatus, Bergsträsser, 1778), a name he obtained from the 1758 edition of Systema Naturae. ${ }^{150}$ On the slip, which was contained within the Solander box of slips for specimens which fell under the Linnaean order of Coleoptera, Solander has added the abbreviation 'MB', which stands for 'Museum Britannicum', indicating that there is an example of this species in the museum collection. Alongside this is a reference to the specific page and description in the 1758 edition of Systema Naturae. ${ }^{151}$ As was the case with the plants, Solander added a reference on his manuscript slip to the publication in which there is an image based on this particular specimen, in this case James Petiver's Gazophylacium (1702-6). ${ }^{152}$ This allowed naturalists using the collection to associate this early publication with Linnaean naming practices and methods of ordering. Solander's use of these images and his manner of relating them to the physical specimens, in the form of his citation of the specific figure in the copper plate image on his manuscript slip, emphasises the importance of these specimens for supporting the descriptions in Linnaeus' works. In cases where he had no direct access to specimens, Linnaeus often based descriptions of species on images in publications, demonstrating the essential part these depictions played in the practice of natural history throughout the eighteenth century. ${ }^{153}$ 
The ability to use these 'Manuscript Slip Catalogues' for the full range of natural history specimens in Sloane's collection shows that this was an efficient method for applying a standardised Linnaean information management system to the British Museum's natural history collection. This conformed to the Linnaean practices of naming and description whilst preserving an arrangement which relates to earlier systems of classification, showing that naturalists, even if they rejected Linnaeus' sexual system of classification, had to use a Linnaean organisation when working with a collection. ${ }^{154}$ The application of similar information management systems to natural history collections throughout Europe was crucial for the relative success and widespread use of Linnaean systematics by the first decade of the nineteenth century.

\section{Conclusion}

Solander's work on the natural history collections of the British Museum was essential for developing one of the first modern museum cataloguing systems, opening the collection to the full range of European naturalists during the 1760s. The reclassification of Sloane's natural history specimens was a major moment in the development of the first public museum, showing clear differences in how a public collection was managed when compared to those administered by private individuals. Figures such as Peter Collinson and William Watson, who wholeheartedly accepted Linnaean systematics, used their influence as Trustees of the British Museum to ensure that Solander was employed to reclassify the collection. Yet, the very nature of the Museum, as the first institution of its kind which had a distinct public remit, ensured that Solander could not completely overhaul the collections so they conformed to Linnaean methods. Rather, he had to devise a new type of information management which ensured that both Linnaean naturalists and those who followed earlier systems could continue to use the collection, laying a new Linnaean method for the location and classification of 
specimens over those used by Sloane. This established a Linnaean information management system, capable of being used by naturalists even if they did not necessarily agree with Linnaeus's sexual system of classification.

The desire to preserve Sloane's legacy is reflected in the physical layout of the collection at Montague House. The furniture designed by Phillips, modelled on Sloane's original cabinets and cases, ensured that the natural history collection remained in its original physical state. This meant that Solander had to apply certain aspects of the Linnaean methodology, such as binomial naming practices, without rearranging the collection. The attempts to preserve the Sloane collection at the British Museum, whilst ensuring that it was accessible to a full range of naturalists, is essential for understanding a time when natural history collections started to be appreciated for their historical integrity in addition to how they could continue to add to natural knowledge. It is clear that it was still seen as vital for naturalists who consulted Sloane's collection to use the annotated copy of A Voyage to Jamaica alongside Solander's labels and manuscripts, which he based on Species Plantarum. Solander's actions made Sloane's collection a fixed reference point for a full range of naturalists who used Ray and Linnaeus' systems. They established the British Museum as one of the principal research centres for naturalists during this period, something which was not attempted again until the mid-nineteenth century. ${ }^{155}$

Solander's continued reference to a range of earlier and contemporary printed books in his new information management system shows how these publications interacted with natural history collections. Solander's use of works such as Joseph Banks's copy of A Voyage to Jamaica as a means for locating and reclassifying specimens casts this printed book, arranged according to Ray's system, as a palimpsest of classification systems, over which Solander laid his new Linnaean catalogue — even whilst continuing to value the existing information. Earlier publications associated with Sloane's collection could then be consulted 
in relation to Solander's 'Manuscript Slip Catalogue', his copy of Linnaeus' Species Plantarum, and the newly labelled specimens in the collection, effectively creating a Linnaean information management system which reclassified the collection without removing its earlier physical arrangement. Solander's use of more flexible paper technologies — most notably his 'Manuscript Slip Catalogue'—alongside bound volumes represents a significant shift from practices more commonly seen in the late seventeenth century to those seen in the early nineteenth century, effectively initiating the widespread use of modern museum cataloguing systems.

The relationship between Solander's new Linnaean order of information and earlier natural history publications is perhaps best represented in his continued interest in the relationship between printed images and physical specimens. These images were essential for adding legitimacy to Solander's reclassification; many of these engravings formed the basis for the descriptions used by Linnaeus in Species Plantarum and Systema Naturae. Several of the systems of information management developed by Solander to reclassify the British Museum's natural history collection could be adapted to work in a number of different spaces and settings. In 1768, Solander wrote to the Trustees of the British Museum to apply for leave to accompany Joseph Banks on James Cook's first voyage to the Pacific; his main purpose was 'to make observations in the different branches of natural history....and of enriching this Museum with new Subjects'. ${ }^{156}$ The annotated printed books and 'Manuscript Slip Catalogues' Solander had been using to reclassify and catalogue the British Museum's collection accompanied him on Cook's voyage. The successful use of Solander's flexible paper technologies over the course of Cook's voyage created the foundation for widespread use of similar means for organising information on natural history collections in the closing decades of the eighteenth century. 


\section{Address for Correspondence}

Edwin D. Rose, Department of History and Philosophy of Science, University of Cambridge, Free School Lane, Cambridge, CB2 3RH.edr24@cam.ac.uk.

\section{Acknowledgements}

An earlier version of this paper was presented at the British Society for the History of Science Annual Conference 2017 at the University of York. I am indebted to Jim Secord, Nick Jardine, Simon Schaffer, James Poskett and Chris Preston for reading through earlier drafts of this article and offering detailed and invaluable comments and Dominik Hünniger for his advice on the entomological specimens. Additionally, the two anonymous reviewers' detailed comments have proved to be extremely helpful, helping me to refine the argument. For access to the various collections at the Natural History Museum, I thank Mark Carine (Life Sciences), Suzanne Ryder (Entomology), Paul Cooper and Hellen Pethers (Library and Archives). For assisting with access to the British Museum's collections, I thank Francesca Hiller and Kim Sloan. Additionally, the staff of the British Library were most helpful. For generously funding my MPhil. research, I thank the British Society for the History of Science and the Joseph Scott Educational Foundation. For funding my current PhD research, I thank the AHRC.

\footnotetext{
${ }^{1}$ Caroli Linnaeus, Species Plantarum Exhibentes Plantas Rite Cognitas, 2 vols., Stockholm: Laurentii Salvii, 1753; Arthur MacGregor, 'The Life, Character and Career of Sir Hans Sloane', in Arthur MacGregor (ed.)., Sir Hans Sloane: Collector, Scientist, Antiquary, Founding Father of the British Museum, London: British Museum Press, 1994, pp. 29-30.

2 James Delbourgo, Collecting the World: The Life and Curiosity of Hans Sloane, London: Allan Lane, 2017, pp. 303-305.

${ }^{3}$ Frans A. Stafleu, Linnaeus and the Linnaeans: The Spreading of their ideas in systematic botany, 1735-1789, Utrecht: A. Oosthoek’s Uitgeversmaatschappi N. V., 1971, pp. 157, 199, 274.
} 


\footnotetext{
${ }^{4}$ Thomas Traill, '1. Annual Reports of the Trustees of the British Museum. 1822. 2. Synopsis of the Contents of
} the British Museum. 1820. 3. Description of the Marbles, \&c. deposited in the British Museum. 1821', Edinburgh Review or Critical Journal (1823) 38, pp. 379-398, at p. 389.

${ }^{5}$ Ibid., pp. 389-390.

${ }^{6}$ British Museum, Central Archive, Trustees Minutes, (Hereafter BMCATM), vol. I, ff., 3-7; Edwin D. Rose, 'Natural history collections and the book: Hans Sloane's A Voyage to Jamaica (1707-25) and his Jamaican plants', Journal of the History of Collections (2017) 30: 1, pp. -----, at p. 5.

${ }^{7}$ See Hans Sloane, A Voyage to the Islands Madera Barbados, Nieves, St Christophers and Jamaica, with the Natural History of the Herbs and Trees, Four Footed Beasts, Fishes, Birds Insects, Reptiles, \&c. of the last of those Islands, London: Printed for the Author, 1707-25, preface.

${ }^{8}$ Hereafter, this work will be referred to as A Voyage to Jamaica. Sloane, op. cit. (7); Rose, op. cit. (6), p. 9.

${ }^{9}$ See Isabelle Charmantier, 'Notebooks, files and slips: Carl Linnaeus and his disciples at work', in Hanna Hodacs, Kenneth Nyberg and Stéphane Van Damme, (eds.)., Linnaeus, natural history and the circulation of knowledge, Oxford: Voltaire Foundation, 2018, pp. 25-56, at p. 25.

${ }^{10}$ Arthur MacGregor, Curiosity and Enlightenment: Collectors and Collections from the Sixteenth to the Nineteenth Century, New Haven and London: Yale University Press, 2007, at pp. 124-125, 233.

${ }^{11}$ See David Elliston Allen, The Naturalist in Britain: A Social History, London: Allen Lane, 1976, at p. 46; Stafleu, op. cit. (3), pp. 113-114, p. 239; Tom Kennett, The Lord Treasurer of Botany: Sir James Edward Smith and the Linnaean Collections, London, The Linnaean Society of London, 2016.

${ }^{12}$ William Hudson, Flora Anglica, exhibens Regnuim sponte crescents distributes Secundum Systema Sexuale, London: J. Nourse, 1762; Thomas Martyn, Plantce Cantabrigienses, or, a Catalogue of the Plants Which grow wild in the County of Cambridge, Disposed according to the system of Linnaeus, London: Printed for the Author, 1763.

${ }^{13}$ See Roy Porter, The Making of Geology: Earth Science in Britain 1660-1815, Cambridge: Cambridge University Press, 1977, p. 93; George S. Rousseau and Roy Porter (eds.), The Ferment of Knowledge: Studies in the Historiography of Eighteenth-Century Science, Cambridge: Cambridge University Press, 1980.

${ }^{14}$ John Gascoigne, Joseph Banks and the English Enlightenment: Useful Knowledge and Polite Culture, Cambridge: Cambridge University Press, 1994, at p. 73.

${ }^{15}$ See: Hanna Hodacs, Kenneth Nyberg and Stéphane Van Damme (eds.)., Linnaeus, natural history and the circulation of knowledge, Oxford: Voltaire Foundation, 2018; Lisbet Koerner, 'Purposes of Linnaean travel: a 
preliminary research report', in David Philip Miller and Peter Hanns Reill (eds.)., Visions of Empire: Voyages, Botany and Representations of Nature, Cambridge: Cambridge University Press, 1996, pp. 117-152, in particular pp. 125-131.

${ }^{16}$ Stafleu, op. cit. (3), p. 199.

${ }^{17}$ Phillip R. Sloan, 'John Locke, John Ray, and the Problem of the Natural System', Journal of the History of Biology (1972) 5, pp. 1-53, at pp. 4-5.

${ }^{18}$ Staffan Müller-Wille, 'Systems and how Linnaeus looked at them in retrospect', Annals of Science (2013) 70, pp. 305-317, at p. 306.

${ }^{19}$ Sydney Howard Vines, 'Robert Morrison 1620-1683 and John Ray 1627-1705', in F. W. Oliver (ed.)., Makers of British Botany: A Collection of Biographies by Living Botanists, Cambridge: Cambridge University Press. 1913, pp. 36-37.

${ }^{20}$ Charlie Jarvis, Mark Spencer and Robert Huxley, 'Sloane's Plant Specimens at the Natural History Museum', in Alison Walker, Arthur MacGregor and Michael Hunter (eds.)., From Books to Bezoars: Sir Hans Sloane and his Collections, London: The British Library, 2012, p. 141.

${ }^{21}$ Rose, op. cit. (6), p. 9.

${ }^{22}$ John F. Cannon, 'Botanical Collections', in Arthur MacGregor (ed.). Sir Hans Sloane: Collector, Scientist, Antiquary, Founding Father of the British Museum, London: British Museum Press, 1994, pp. 138-49 at p. 137.

${ }^{23}$ J. E. Dandy, The Sloane Herbarium: An Annotated list of the Horti Sicci composing it: with biographical accounts of the principal contributors, London: British Museum (Natural History), 1958, pp. 175, 178.

${ }^{24}$ Cannon, op. cit. (22), p. 136.

${ }^{25}$ John Ray, Historia Plantareum Species hactenus editas aliasque insuper muitas noviter inventas \& descriptas complectens, 3 vols., London: Henry Faithorne and John Kersey, 1686-1704, containing annotations by Hans Sloane and his curators, London, Natural History Museum (NHM), Darwin Centre, DC2 HCR 728, vol. III, p. 613.

${ }^{26}$ Rose, op. cit. (6), p. 6.

${ }^{27}$ For more information on Sloane's precise use of Ray's system of classification in his personal herbarium collections, see Rose, op. cit. (6).

${ }^{28}$ Müller-Wille, op. cit. (18), pp. 310-311.

${ }^{29}$ Stafleu, op. cit. (3), p. 120.

${ }^{30}$ Ibid., p. 211. 
${ }^{31}$ Rose, op. cit. (6), p. 7; Sloane, op. cit. (7), p. 107.

${ }^{32}$ Ray, DC2 HCR 728, op. cit. (25), vol. 3, p. 600; Caroli Linnaeus, Species Plantarum, Exhibentes Plantas Rite Cognitas, 2nd edn., 2 vols., Stockholm: Laurentii Salvii, 1762-1763, p. 1379.

${ }^{33}$ Rose, op. cit. (6), p. $9-10$.

${ }^{34}$ Jarvis, Spencer and Huxley, op. cit. (20), p. 139.

${ }^{35}$ William T. Stearn, Three prefaces on Linnaeus and Robert Brown, Weinheim: J. Cramner, 1962, p. x.

${ }^{36}$ MacGregor, op. cit. (1), p. 26. Marjorie Caygill, 'From Private Collection to Public Museum: The Sloane

Collection at Chelsea and the British Museum at Montague House', in R. G. W. Anderson, M. L. Caygill, A. G.

MacGregor and L. Syson (eds.)., Enlightening the British: Knowledge, discovery and the museum in the eighteenth century, London: British Museum Press, 2003, pp. 18-36, at pp. 20-21.

${ }^{37}$ Marjorie Caygill, 'Sloane's Will and the Establishment of the British Museum', in Arthur MacGregor (ed.)., Sir Hans Sloane: Collector, Scientist, Antiquary, Founding Father of the British Museum, London: British Museum Press, 1994, pp. 45-68, at pp. 48-49; Sloane, op. cit. (7), p. 17-19.

${ }^{38}$ A. E. Gunther, The Founders of Science at the British Museum, 1753-1900, Suffolk: Halesworth Press, 1980, p. 13.

${ }^{39}$ James Empson, 'A Proposal of a Plan', laid before the Trustees of the British Museum, 29 August 1756.

British Museum, Central Archive, Original Papers (Hereafter, BMCAOP), vol. 1, fols., 39-45.

${ }^{40}$ Ibid., fols., 39-45. Empson gave six private tours of Sloane's manor between 1754 and 1756.

${ }^{41}$ Cromwell Mortimer, 'An Account of the Prince and Princess of Wales Visiting Sir Hans Sloane', The Gentleman's Magazine and Historical Chronicle (1748) 17, pp. 301-302, p. 301.

${ }^{42}$ BMCAOP, op. cit. (39) fols., 40-44.

${ }^{43}$ BMCATM, op. cit. (6), vol. 1., f. 94.

${ }^{44}$ BMCATM, op. cit. (6), vol. 1, f. 74; for images of Sloane's original cabinets, see Rose, op. cit. (6), pp. 4-5.

${ }^{45}$ Ibid., f. 78.

${ }^{46}$ British Museum, Central Archive, Plans by Fitzroy and Brazier, Uncatalogued.

${ }^{47}$ Empson, BMCAOP op. cit. (39), f. 40.

${ }^{48}$ Ibid., f. 40.

${ }^{49}$ BMCATM, op. cit. (6), f. 4.

${ }^{50}$ Empson, BMCAOP, op. cit. (39), f. 40.

${ }^{51}$ Ibid., f. 40. 
${ }^{52}$ Edmund Powlett, The General Contents of the British Museum: With Remarks. Serving as a Directory in viewing that Noble Cabinet, London: R. and J. Dodsley, 1761, at p. 101.

${ }^{53}$ Mortimer, op. cit. (41), p. 301.

${ }^{54}$ Letter from Peter Collinson to William Watson, 5 October 1762, BMCAOP, op. cit. (39), f. 174.

${ }^{55}$ Gunther, op. cit. (38), p. 15.

${ }^{56}$ Acts and Votes of Parliament relating to The British Museum, with the Statutes and Rules Thereof, and the Succession of Trustees and Officers, London: G. Woodfall, 1824, at p. 5.

${ }^{57}$ Delbourgo, op. cit. (2), p. 320.

${ }^{58}$ Ibid, p. 320.

${ }^{59}$ Anne Goldgar, 'The British Museum and the Virtual Representation of Culture in the Eighteenth Century', Albion, (2000) 32, pp. 195-231, at p. 203.

${ }^{60}$ Quoted in Goldgar, op. cit. (59), p. 204.

${ }^{61}$ Patricia Fara, “A treasure of hidden ventures': the attraction of magnetic marketing', The British Journal for the History of Science 28 (1995), pp. 5-35, at p. 10; Gunther, op. cit. (38), p. 13; Goldgar, op. cit. (59) p. 203; William T. Stearn, The Natural History Museum at South Kensington: A History of the British Museum (Natural History) 1753-1980, London: Heinemann, 1981, at p. 14.

${ }^{62}$ Gowin Knight, ‘A Plan for the General Distribution of Sir Hans Sloane’s Collection', BMCAOP, op. cit. (39), fols., 51-53; Gunther, op. cit. (---), p. 14.

${ }^{63}$ Knight, BMCAOP, op. cit. (39) f., 52.

${ }^{64}$ Staffan Müller-Wille, 'Linnaeus' herbarium cabinet: a piece of furniture and its function', Endeavour (2006) 30, pp. 60-64, at p. 60; Caroli Linnaeus, Philosophia Botanica, Stockholm: Godofr Kiesewetter, 1751, p. 309; Stephen Freer, Linnaeus' Philosophia Botanica, Oxford: Oxford University Press, 2005, p. 328-329.

${ }^{65}$ Müller-Wille, op. cit. (64), pp. 61-63.

${ }^{66}$ Freer, op. cit. (64), p. 329.

${ }^{67}$ Müller-Wille, op. cit. (64), p. 61-62.

${ }^{68} \mathrm{H}$. Clokie, An account of the herbaria of the department of botany in the University of Oxford, Oxford: Oxford University Press, 1964, p. 107.

${ }^{69}$ William Watson, 'An Account on a Treatise in Latin, entitled Caroli Linnæi Serenissimae regiæ majestatis Sueciæ Archiatri regæ... with remarks', The Gentleman's Magazine and Historical Chronicle, (1754) 24, pp. 555-558, at p. 558. 
${ }^{70}$ Lysaght, Avril. M., Joseph Banks in Newfoundland and Labrador, 1766, His Diary, Manuscripts and Collections, Berkley and Los Angeles: University of California Press, 1971, at p. 242. Madrepodology was the study of corals.

${ }^{71}$ Oliver Goldsmith, An History of the Earth and Animated Nature, London: J. Nourse, 1774, p. viii-ix; Ralph Brookes, The Natural History of Vegetables, London: J. Newbery, 1763, at p. v.

${ }^{72}$ Phillip R. Sloan, 'The Buffon-Linnaeus Controversy’, Isis (1976) 67, pp. 356-375, at p. 369.

${ }^{73}$ Gunther, op. cit. (38), p. 39; John B. Marshall, 'Daniel Carl Solander, friend, librarian and assistant to Sir Joseph Banks', Archives of Natural History (1984) 11, pp. 451-456; MacGregor, op. cit. (10), pp. 124-125.

${ }^{74}$ Albert. E. Gunther, 'Matthew Matty MD, FRS (1718-76) and Science at the Foundation of the British Museum, 1753-80', Bulletin of the British Museum (Natural History) (1987) 15, pp. 1-58, at p. 39.

${ }^{75}$ Alan W. Armstrong, (ed.)., 'Forget not Mee \& My Garden': Selected letters, 1725-1768, of Peter Collinson, F. R. S., Philadelphia: American Philosophical Society, 2002, p. 161.

${ }^{76}$ Collinson, BMCAOP, op. cit. (39), fols., 173-v174.

${ }^{77}$ Ibid., fols. 173-v174; Armstrong, op. cit. (39), p. 160.

${ }^{78}$ Collinson, BMCAOP, op. cit. (39), fols., 173-v174.

${ }^{79}$ Ibid., f. 178; Goldgar, op. cit. (59), p. 216.

${ }^{80}$ Collinson, BMCAOP, op. cit. (39), f. 175; Edward Duyker and Per Tingbrand (eds.)., Daniel Solander:

Collected Correspondence, 1753-1782, Melbourne: Miegunyah Press, 1995, p. 253.

${ }^{81}$ See Rose, op. cit (6). For plants, see pp. 4-12; for shells, see p. 14.

${ }^{82}$ Daniel Solander, 'Reports and Diary of occurrences in the Nat. hist. departments by Dr. Solander. Sept. 1764Feb. $12^{\text {th }} 1768^{\prime}$, British Library (hereafter BL), Add MSS 45, 874, f. 6.

${ }^{83}$ Rüdiger Joppien and Neil Chambers, 'The Scholarly Library and Collections of Knowledge of Sir Joseph Banks', in Giles Mandelbrote and Barry Taylor (eds.)., Libraries within the Library: The Origins of the British Library's Printed Collections, London: British Library, 2009, pp. 222-243, at p. 26.

${ }^{84}$ Harold. B. Carter, 'Sir Joseph Banks and the Royal Society', in R. E. R. Banks, B. Elliot, J. G. Hawkes, D. King-Hele and G. L. Lucas (eds.)., Sir Joseph Banks: A Global Perspective, London: Royal Botanic Gardens Kew, 1994, at p. 2.

${ }^{85}$ Anne Goldgar, Impolite Learning: Conduct and Community in the Republic of Letters, 1680-1750, New Haven and London: Yale University Press, p. 22; See Neil Chambers (ed.)., Scientific Correspondence of Sir Joseph Banks, 1765-1820, volume 1, the Early Period, 1765-1784, Letters 1765-1782, London: Pickering and 
Chatto, 2007, vol. 1., pp. 136-137. In 1775, Poore presented 'a Tree frog, a large scarabous (Beetle) a grass hopper and 2 very scarce Land Shells, all collected at Jamaica' to the British Museum. This was recorded by Solander in his department note book, BL Add MSS 45, 875, op. cit. (82), f. 10.

${ }^{86}$ Banks's early bookplate in the front of this volume shows that he purchased it before he set out on the Endeavour in 1768. See Harold B. Carter, Sir Joseph Banks (1743-1820): A guide to biographical and Bibliographical Sources, London: St Paul's Bibliographies in association with the British Museum (Natural History), 1987, plates 2-4.

${ }^{87}$ The annotated location codes in Sloane's copy of A Voyage to Jamaica are in the hand of Sloane himself. ${ }^{88}$ Gascoigne, op. cit. (14), p. 101; Joppien and Chambers, op. cit. (83) p. 226; Harold. B. Carter, Sir Joseph Banks: 1743-1820, London: British Museum (Natural History), 1988, pp. 27-28; Hans Sloane, A Voyage to the Islands Madera, Barbados, Nieves, S. Christophers and Jamaica, with the Natural History of the Herbs and Trees, Four-footed Beasts, Fishes, Birds, Insects, Reptiles, \&c. of the last of those Islands, London: Printed for the Author, 1707-1725, annotated by Daniel Solander and Sir Joseph Banks, who took this book on the Endeavour voyage to the South Seas (1768-1771); and Olaf Swartz. NHM, Botany Special Collections, Darwin Centre, DC2 HCR 728. See Joseph Banks and Joseph Hooker (ed.)., Journal of the Right Hon. Sir Joseph Banks, London: Macmillan, 1896, pp. 12, 273. This copy must be handled with caution—on a number of occasions, later scholars and curators have erased Solander's binomials and replaced them with the more modern synonyms, the most prolific being Olaf Swartz (1760-1818).

${ }^{89}$ Sloane, op. cit. (88), p. 107; Manuscript descriptions of Plants, written on slips of paper and systematically arranged, the Phanerogams and Vascular Cryptogams in accordance with Wildenow's edition of Linné's "Species Plantarum," the Cellular Cryptogams by Richard's edition of that work : the slips, now bound in 24 volumes, were originally kept in small Solander Cases, and designed to form a complete catalogue of the species of Plants then known', NHM, London, Botany Manuscripts, MSS BANKS COLL SOL. Hereafter referred to as 'Manuscript Slip Catalogue', Vol. XVIII, f. 167.

${ }^{90}$ Lisbet Koerner, Linnaeus: Nature and Nation, Cambridge, MA: Harvard University Press, 1999, pp. 45-46; Gunnar Eriksson, 'Linnaeus the Botanist', in Tore Frängsmyr, Linnaeus: The Man and His Works, Berkley: University of California Press, 1983, pp. 102-103.

${ }^{91}$ Sloane, op. cit. (88), vol. I., p. 107; Linnaeus, op. cit. (32), p. 1379. The first seven volumes of Sloane's herbarium have been digitised by the NHM and can be found at: http://www.nhm.ac.uk/researchcuration/scientific-resources/collections/botanical-collections/sloane-herbarium/. 
${ }^{92}$ Daniel Solander, 'An Account of the Gardenia: In a Letter to Philip Carteret Webb, Esq; F.R.S. From Daniel

C. Solander', Philosophical Transactions (1762) 52, pp. 654-661, at p. 659.

${ }^{93}$ See Elizabeth Yale, Sociable Knowledge: Natural History and the Nation in Early Modern Britain,

Philadelphia: University of Pennsylvania Press, 2016, p. 165.

${ }^{94}$ See David Seposki, 'The Earth as Archive: Contingency, Narrative and the History of Life', in Lorraine

Daston (eds.)., Science in the Archives: Pasts, Presents and Futures, Chicago and London: University of

Chicago Press, 2017, pp. 53-84, at pp. 74-75.

${ }^{95}$ Yale, op. cit. (93), p. 165; John Harrison, The Library of Isaac Newton, Cambridge: Cambridge University Press, 1978, p. 20-22.

${ }^{96}$ NHM, London, HCR, Sloane Herbarium, H. S. 211. See Petra-Andrea Hinz, 'The Japanese plant collection of Engelbert Kaempfer (1651-1716) in the Sir Hans Sloane Herbarium at the Natural History Museum, London', Bulletin of the Natural History Museum, London (2001) 31, pp. 27-34.

${ }^{97}$ Engelbert Kaempfer, Amoenitatum exoticarum Politico-Physico-Medicarum Fasciculi V, Lemgo: Mayer,

1712. Banks's copy, which has been annotated by Solander, can be found in the British Library, shelf mark BL 440.k.1.

${ }^{98}$ Solander, BL Add MS. 45, 874, op. cit. (82), fols., 6- verso-7.

${ }^{99}$ Kaempfer, op. cit. (97), pp. 891.

${ }^{100}$ Arthur MacGregor, 'The Ashmolean as a museum of natural history, 1683-1860', Journal for the History of Collections (2001) 13, pp. 125-144, at pp. 137-138.

${ }^{101}$ Ibid., p. 137. Arthur MacGregor, 'William Huddesford (1732-72): The Ashmolean Museum, his collections, researches, and support networks', Archives of Natural History (2007) 34, pp. 47-68; Ken Arnold, Cabinets for the Curious: Looking back at Early English Museums, Aldershot: Ashgate, 2006, pp. 227-228.

${ }^{102}$ Daniel Solander, A report to the Trustees of the British Museum, January, 1765, BMCAOP, f. 201.

${ }^{103}$ Gunther, op. cit. (74), p. 40; Stearn, op. cit. (61), pp. 18-19.

${ }^{104}$ Solander, BL Add. MS 45874,op. cit. (82), f. 2 verso.

${ }^{105}$ Letter from Daniel Solander to William Watson, 26 January 1763, BMCAOP, op. cit. (39), f. 176.

${ }^{106}$ Staffan Müller-Wille, and Isabelle Charmantier, 'Natural history and information overload: The case of Linnaeus', Studies in History and Philosophy of Biological and Biomedical Sciences (2012) 43, pp. 4-15, at p. 4. These cards were consistently re-arranged as new editions of Linnaeus' works were published throughout the late eighteenth century. They have since been bound together into 24 volumes, probably during the mid- 
nineteenth century, according to the edition of Species Plantarum edited by Carl Ludwig Willdenow. This was the first recorded use of Solander boxes, a type of protective clam-shell case used for storing documents, to which Solander gave his name.

${ }^{107}$ Isabelle Charmantier and Staffan Müller-Wille, ‘Carl Linnaeus’ botanical paper slips (1767-1773), Intellectual History Review (2014) 24, pp. 215-238, at p. 218; Solander, BL Add MSS 45, 874, op. cit (82), f. 6.

${ }^{108}$ Charmantier and Müller-Wille, op. cit. (107), p. 230.

${ }^{109}$ Ibid., p. 230.

${ }^{110}$ Daniel Solander to the Trustees of the British Museum, 29 June 1765, BMCAOP, op. cit. (39), f. 211.

${ }^{111}$ Daniel Solander to the Trustees of the British Museum, 13 February 1765, BMCAOP, op. cot. (39), f. 211; Duyker and Tingbrand, op. cit (81) p. 265.

${ }^{112}$ Gunther, op. cit. (74), p. 40; John B. Marshall, 'The Handwriting of Joseph Banks, his Scientific Staff and his amanuenses', Bulliten of the Britidh Museum (Natural History), (1978) 6, pp. 1-85, at pp. 2-4.

${ }^{113}$ Solander, BL, Add MS 45, 874, op. cit. (82), f. 8.

${ }^{114}$ BMCATM, op. cit. (6), f. 4.

${ }^{115}$ Müller-Wille and Charmantier, op. cit. (106), p. 10.

${ }^{116}$ Gunther, op. cit. (74), p. 40.

117 'Descriptions of plants from various parts of the world', Daniel Solander and Hermann Spöring, MSS BANKS COLL SOL, NHM, London.

${ }^{118}$ Richard Yeo, Notebooks, English Virtuosi, and Early Modern Science, Chicago and London: University of Chicago Press, 2014), p. xi.

${ }^{119}$ Charmantier and Müller-Wille, op. cit. (107), p. 216.

120 'Manuscript Slip Catalogue’, op. cit. (89), f. 433; Leonardi Plukenetii, Phytographia, sive Stripium illustriorum, \& minus cognitarum icons, tabulis aeneis, summa diligentia elaboratae, London: Published for the Author, 1691

121 'Manuscript Slip Catalogue’, op. cit. (89), f. 433; Anna Marie Roos, ‘The Art of Science: A ‘Rediscovery’ of the Lister Copperplates', Notes and Records of the Royal Society (2012) 66, pp. 19-40, at p. 20.

${ }^{122}$ Sloane, op. cit. (88), table 106, fig. 2.

${ }^{123}$ Jarvis, Spencer and Huxley, op. cit. (20), p. 139; H. S. 3. :40, op. cit. (96).

${ }^{124}$ Emma C. Spary, 'Codes of Passion: Natural History Specimens as a Polite Language in Late $18^{\text {th }}$-Century France', in Hans Erich Bödeker, Peter Hanns Reill and Jürgen Schlumbohm, (eds.). Sonderdruck aus 
Wissenschaft als kulturelle Praxis, 1750-1900, Göttingen: Vandenhoeck \& Puprecht, 1999, pp. 114-6; Mary Terrall, Catching Nature in the Act: Réaumur and the Practice of Natural History in the Eighteenth-Century, Chicago: University of Chicago Press, 2014, pp. 114.

${ }^{125}$ See Martin J. S. Rudwick, 'Picturing Nature in the Age of Enlightenment', Proceedings of the American Philosophical Society (2005) 149, pp. 124-130.

${ }^{126}$ Sloane, op. cit. (88), p. 144.

${ }^{127}$ Marshall, op. cit. (112), p. 4; Caroli Linnaeus, Species Plantarum, Exhibentes Plantas Rite Cognitas, 2nd edn. Stockholm: Laurentii Salvii, 1762-1763. This copy was taken on the Endeavour by Joseph Banks and Daniel Solander, extensively interleaved and in six volumes. Much of the writing is in the hand of Hermann Spöring, Daniel Solander and Jonas Dryander. London, NHM, Botany Special Collections, 582 LINN 110, pp. 1369-1370. Unfortunately, Solander's copy of the 1758 edition of Systema Naturae cannot be traced.

${ }^{128}$ This type of referencing was used by Solander in the zoological sections of the Manuscript Slip Catalogue.

${ }^{129}$ Linnaeus, op. cit. (127), p. 1405.

${ }^{130}$ Gordon McOuat, 'Cataloguing Power: Delineating 'Competent Naturalists' and the Meaning of Species in the British Museum', British Journal for the History of Science (2001) 34, pp. 1-28, at p. 7.

${ }^{131}$ Marshall, op. cit. (112), p. 4; Gascoigne, op. cit, (14), p. 105.

${ }^{132}$ Marshall, op. cit. (112), p. 452.

${ }^{133}$ Marshall, op. cit. (112), p. 4.

${ }^{134}$ Gascoigne, op. cit. (14), p. 105-106.

${ }^{135}$ Dandy, op. cit. (23), p. 205; Marshall, op. cit. (112), pp. 8-9.

${ }^{136}$ Sloane, op. cit (88), vil. 1, p. 74; Linnaeus, op. cit. (127).

${ }^{137}$ H. S. 1: 64, op. cit. (96); Sloane, op. cit. (88), p. 74; Linnaeus, op. cit. (127), p. 719.

${ }^{138}$ Rose, op. cit. (6), pp. 11-12.

${ }^{139}$ Terrall, op. cit. (124), p. 160; For more on the authority added to a specimen by a label, see Jim Endersby, Imperial Nature: Joseph Hooker and the Practices of Victorian Science, Chicago: University of Chicago Press, 2008, pp. 138-143.

${ }^{140}$ Sloane, op. cit. (88), p. 74.

${ }^{141}$ Later users of this collection included figures such as Olaf Swartz (1760-1818), who conducted extensive researches on Sloane's collection from 1786-87.

${ }^{142}$ Solander BL Add MS 45, 874, op. cit. (82), f. 2. 
${ }^{143}$ John Ray, Historia Insectorum, London: A. \& J. Churchill, 1710); C. E. Raven, John Ray, Naturalist,

Cambridge: Cambridge University Press, 1942, pp. 398-403.

${ }^{144}$ Raven, op. cit. (143), pp. 406-407.

${ }^{145}$ Mary P. Winsor, 'The Development of Linnaean Insect Classification', (1976) 25, Taxon, pp. 57-67, at p. 62.

${ }^{146}$ Ibid., p. 57.

${ }^{147}$ Mike Fitton and Pamela Gilbert, 'Insect Collections’, in Arthur MacGregor (ed.)., Sir Hans Sloane:

Collector, Scientist, Antiquary, Founding Father of the British Museum, London: British Museum Press, 1994,

pp. $112-122$, at pp. $118-119$.

${ }^{148}$ Solander, BL Add MS 45, 874, op. cit. (82), f. 2.

${ }^{149}$ After examining the entirety of Sloane's entomological collection, it is now apparent that many of Solander's labels appear to have been removed during the early nineteenth century and replaced with names which relate to more recent taxonomic literature, possibly by Charles Koenig, keeper of the natural history collections from $1813-51$.

${ }^{150}$ Caroli Linnaeus, Systema Natura, Stockholm: Laurentii Salvii, 1758, p. 421.

${ }^{151}$ Daniel Solander, 'Manuscript descriptions of Animals, written on slips and systematically arranged in accordance with Linné's "Systema Naturæ...Edito duodecima reformata.": the slips, now bound in 27 volumes were originally kept in small Solander Cases, and designed to form a complete catalogue of the species of Animals then known., vol. III, Coleoptera, f. 73. NHM, London.

${ }^{152}$ James Petiver, Gazophylacii naturce \& artis decas prima, 3 vols., London: Bateman, 1702-6, vol. 1, at table 72.

${ }^{153}$ Roos, op. cit. (121), p. 20; Sachiko Kusukawa, Drawings of fossils by Robert Hooke and Richard Waller', Notes and Records of the Royal Society (2013) 67, pp. 123-138, at p. 273.

${ }^{154}$ This was also the case in botanic gardens; see Koerner, op. cit. (90), p. 119.

${ }^{155}$ See, McOuat, op. cit. (130).

${ }^{156}$ Daniel Solander in a Report to the Trustees of the British Museum, 24 June 1768, BMCAOP, op. cit. (39), f. 225. 